dynamics and of the experimental side of electrostatics, and a chapter on forced vibrations and resonance in the section on acoustics. There are also many more numerical examples for solution.

Dr. Smith holds strong views about the MKS system, which one gathers he would not touch with a pole; and his comment on units in the preface may seem a little sweeping. His mastery of the orthodox approach in the sections on electricity, and the general excellence of its presentation, nevertheless compel one's admiration.

G. R. NOAKES

\section{Principles of Engineering Heat Transfer}

By Prof. Warren H. Giedt. Pp. xiii +372 . (Princeton, N.J., and London: D. Van Nostrand Company, Inc., 1957.) 48s. net.

$\mathrm{N}$ view of the extensive literature of the subject, 1 the number of text-books on heat-transfer is surprisingly few and makes this new addition especially welcome. The author has rightly devoted the major part of the work to a fundamental exposition of the basic principles, avoiding embroilment in the jungle of empirical data which has grown up with the development of this subject. The book follows the natural division of heat-transfer into the three modes of conduction, convection and radiation, all of which are treated with admirable clarity. The order of treatment is, however, somewhat unusual, the separation to opposite ends of the book of the chapters on steady-state and transient conduction appearing to serve no useful purpose. The relegation to the last chapter of the concept of logarithmic mean temperature difference, which is so fundamental in the study of heat-exchange equipment, is also a less desirable feature of the book. Convection is preceded by two chapters on fluid flow which in the main are most helpful to an understanding of convective heattransfer principles. There are, however, certain superfluities for a book of this kind, the most noticeable of which is the inclusion of the elementary theory of orifice and venturi meters.

Among the commendable features of the book are the summary of the principles of the heat and momentum transfer analogy in the solution of turbulent convection problems, including the extension to the special problem of liquid metals, and the description of electric analogue methods in the solution of conduction problems.

The book will be extremely useful to the student at university degree-level but would have been improved by the inclusion of numerical answers to the many end-of-chapter problems, a deficiency which, alas, is a common failing of almost every text-book of American origin.

H. COHEN

\section{Die Bluteiweisskörper des Menschen}

Untersuchungsmethoden und deren klinischpraktische Bedeutung. Von Prof. Ferdinand Wuhrmann und Dr. Charlie Wunderly. Dritte völlig umgearbeitete Auflage. Pp. 499. (Basel und Stuttgart : Benno Schwabe and Co., 1957.) 52 Swiss francs.

$\mathrm{T}$ $1 \mathrm{HE}$ previous two editions of this treatise, published in 1947 and 1951, were, perhaps, much better known on the Continent than in Britain because no English versions were available. This edition is an extensive revision and enlargement of the former editions. A welcome feature is the prominence now given to paper electrophoretic and agar gel immunoelectrophoretic techniques. Here, at last, is a book which brings together so many illustrations of abnormal plasma protein patterns. Another feature is the thorough discussion of the traditional techniques of free electrophoresis, ultracentrifugation and salting out. Routine clinical methods for blood examination are also well covered; the clinical significance of the plasma proteins, their evaluation and their alteration in disease are comprehensively discussed.

There is a tendency, perhaps understandable, to refer more to German than to non-German sources, but consequently some important work is overlooked or not given the attention it deserves. Recent techniques of zone electrophoresis in columns or slabs or of ion exchange chromatography are not mentioned though they have been used with striking success for plasma protein separation. In such a detailed book the subject index might perhaps be fuller. However, there is a good balance between the physico-chemical and clinical sides and in this respect the book is exceptional. Each of the authors is a specialist in each field and they have collaborated for many years in clinical investigations. Though rather expensive the price is not too high for such an attractively printed, comprehensive reference work. Its appeal would undoubtedly be widened if an English version was available. R. CONSDEN

\section{Selected Lectures in Modern Physics for School Science Teachers}

Edited by Prof. H. Messel. Pp. 168. (Sydney : Nuclear Research Foundation within the University of Sydney, 1958.) $30 s$.

N January of this year the Nuclear Physics Foundation of the University of Sydney held a summer school for science teachers. This was not just a refresher course to attack or remove the outer layers of rust. Its expressed intention was to infect the participants with an inspiration which they would spread, and the direct aim a second-order effect on the future entrants to the faculties of science and engineering. This record of the proceedings, which was made available at the end of the school (in itself a remarkable feat of publishing), is both a worthy tribute to the venture itself and an excellent survey of many fields of modern physics.

The twenty-four lectures range widely, and the topics seem to have been chosen for their general interest; they are the matters on which a teacher would very properly be expected to be able to answer questions. Nuclear energy; low-, high-, and ultrahigh energy nuclear physics; 'strange' particles ; physics in rain-making; Newton's laws of motion and space-travel; radioastronomy; how to talk to an electronic brain; transistors; the use of isotopes in medicine; physics in geology ; measurement; and cosmic radiation; these are among the main subjects selected. There are also an instructive account of the building of relatively simple apparatus for demonstration experiments in electronics and nuclear physics, and a discussion of careers in physics, and of the need of suitable candidates for them.

The lecturers themselves are to be congratulated on touching just the right level for their audience, and on communicating their obvious enjoyment of their work. I learned a great deal from the book, felt that I understood most of it, and was much impressed by the way it was all presented. The book can be highly recommended to teachers of science, and will be a most valuable acquisition to a school science library.
G. R. NOAKES 